Brit. F. vener. Dis. (1970) 46, 203

\title{
Selective inhibition in vitro of Mycoplasma hominis by lincomycin
}

\author{
GEORGE CSONKA AND JEAN CORSE \\ Central Middlesex Hospital and Wright-Fleming Institute, London
}

M. hominis and the T-strains are the mycoplasmas most commonly isolated from the genital tract of men and women (Shepard, 1954; Ford, 1962; Csonka, Williams, and Corse, 1966). They may be grown from the same clinical material, but the recognition of the small colonies of T-strains can be very difficult in mixed cultures when $M$. hominis is abundant. Shepard, Lunceford, and Baker (1966) found that erythromycin selectively inhibited $\mathrm{T}$-strains in vitro and was helpful in differentiating them from other mycoplasmas. Shipley, Bowman, and O'Connor (1968) and our own group found independently that $\mathrm{T}$-strains were resistant in vitro to high concentrations of lincomycin. Csonka and Spitzer (1969) observed that lincomycin had little or no effect in non-gonococcal urethritis (NGU) and that after a course of this antibiotic, $\mathrm{T}$-strains persisted in the urethral discharge whilst $M$. hominis disappeared.

In the present study, we have investigated the effect of lincomycin in vitro on the growth of $M$. hominis and $\mathrm{T}$-strains.

\section{Material and Methods}

Cotton wool swabs with discharge from the urethra of twelve men with NGU and from the cervix of ten women with cervicitis were used to inoculate two sets of plates of solid medium made up according to Shepard's formula (Shepard, 1967), one of which contained $60 \mu \mathrm{g} . / \mathrm{ml}$. penicillin and the other 5 or $10 \mu \mathrm{g} . / \mathrm{ml}$. lincomycin. In twelve cases a third plate incorporating $10 \mu \mathrm{g} . / \mathrm{ml}$. erythomycin was also inoculated.

\section{Results}

The Table sets out the results. M. hominis was inhibited by 5 and $10 \mu \mathrm{g} . / \mathrm{ml}$. lincomycin whereas Tstrain was not. There were five more isolations of $\mathrm{T}$-strains on the lincomycin-containing media compared with the penicillin control plates. On four of these, $M$. hominis was present and presumably obscured the T-strains. On three other penicillin control plates, both $M$. hominis and T-strain colonies

Received for publication August 22, 1969
TABLE Selective inhibition in vitro of Mycoplasma hominis by lincomycin and of T-strain mycoplasma by erythromycin in 22 cases

\begin{tabular}{|c|c|c|c|c|}
\hline \multirow{2}{*}{$\begin{array}{l}\text { Case } \\
\text { No. }\end{array}$} & \multirow[b]{2}{*}{ Diagnosis } & \multicolumn{3}{|c|}{ Agar plates containing } \\
\hline & & $\begin{array}{l}\text { Penicillin } \\
(60 \mu \mathrm{g} . / \mathrm{ml} .)\end{array}$ & $\begin{array}{l}\text { Lincomycin } \\
(5-10 \mu \mathrm{g} . / \mathrm{ml} .)\end{array}$ & $\begin{array}{l}\text { Erythromycin } \\
(10 \mu g . / m l .)\end{array}$ \\
\hline 1 & NGU & $\mathbf{T}$ & $\mathbf{T}$ & 0 \\
\hline 2 & NGU & $T$ & $T$ & \\
\hline 3 & NGU & $\mathrm{T}$ & $T$ & \\
\hline 4 & NGU & $\mathbf{T}$ & $\mathbf{T}$ & \\
\hline 5 & NGU & $\mathbf{T}$ & $\mathrm{T}$ & \\
\hline 6 & NGU & $\mathrm{T}$ & $\mathbf{T}$ & \\
\hline 7 & NGU & $T$ & $\mathrm{~T}$ & \\
\hline 8 & NGU & $\mathbf{T}$ & $\mathrm{T}$ & \\
\hline 9 & NGU & $\mathrm{T}$ & $\mathrm{T}$ & \\
\hline 10 & NGU & M. hominis & $\mathrm{T}$ & M. hominis \\
\hline 11 & NGU & 0 & 0 & 0 \\
\hline 12 & NGU & 0 & 0 & 0 \\
\hline 13 & Cervicitis & M. hominis & $\mathrm{T}$ & M. hominis \\
\hline 14 & Cervicitis & M. hominis & $\mathbf{T}$ & M. hominis \\
\hline 15 & Cervicitis & M. hominis & $\mathrm{T}$ & M. hominis \\
\hline 16 & Cervicitis & M. hominis $+\mathrm{T}$ & $\mathrm{T}$ & M. hominis \\
\hline 17 & Cervicitis & M. hominis $+\mathrm{T}$ & $\mathrm{T}$ & \\
\hline 18 & Cervicitis & M. hominis + T & $\mathrm{T}$ & \\
\hline 19 & Cervicitis & $\mathrm{T}$ & $\mathrm{T}$ & 0 \\
\hline 20 & Cervicitis & $\mathrm{T}$ & $\mathrm{T}$ & 0 \\
\hline 21 & Cervicitis & 0 & $\mathbf{T}$ & 0 \\
\hline 22 & Cervicitis & 0 & 0 & 0 \\
\hline
\end{tabular}

$0=$ no growth

were seen, whilst on the plates with lincomycin, Tstrains only were noted.

Erythromycin inhibited T-strains without interfering with the growth of $M$. hominis, confirming the observations of Shepard and others (1966).

\section{Discussion}

$M$. hominis and T-strains are not infrequently present together, especially in clinical material from the genital tract of women; thus in 103 women with leucorrhoea, T-strains were isolated in 50.4 per cent. $M$. hominis in 32.0 per cent., and the two organisms were found in the same specimens in 27.0 per cent. (Csonka, 1969). The incorporation of lincomycin is shown to inhibit the growth of $M$. hominis without affecting that of $\mathrm{T}$-strains, and this improves the 
chances of recognizing the small colonies and often sparse growth of $\mathrm{T}$-strains in mixed cultures. Buskirk (1967) recommended the use of lincomycin in cell cultures to keep them free from contamination with mycoplasmas; in view of our findings this may have to be modified with regard to T-strain mycoplasma.

\section{Summary}

Lincomycin has been shown to inhibit the growth of $M$. hominis in vitro but not that of T-strain mycoplasmas; it thus provides a biochemical method of differentiating the two most commonly isolated genital mycoplasmas which are not infrequently both present in the same clinical material. The addition of lincomycin to the culture medium has facilitated and improved the recognition of $\mathrm{T}$-strain mycoplasmas.

We wish to thank Prof. R. E. O. Williams for his helpful advice. The work of one of us (G.C.) was supported by a grant from the Medical Research Council.

\section{References}

Buskirk, H. (1967) Appl. Microbiol., 15, 1442

CsonkA, G. W. (1969) Urol. Digest, 8, 19 and SPITZER, R. J. (1969) Brit. F. vener. Dis., 45, 52 , Williams, R. E. O., and CoRse, J. (1966) Lancet, 1, 1292

FORD, D. K. (1962) f. Bact., 84, 1028

SHEPARD, M. C. (1954) Amer. F. Syph., 38, 113 (1967) Ann. N.Y. Acad. Sci., 143, 505

-, LUNCEFORD, C. D., and BAKER, R. L. (1966) Brit. F. vener. Dis., 42, 21

ShIPleY, A., Bowman, S. J., and O'ConNoR, J. (1968) Med. F. Aust., 1, 794

Inhibition sélective in vitro du Mycoplasma hominis par la lincomycine SOMMAIRE

La lincomycine s'est montrée inhibitrice vis à vis de la pousse de $M$. hominis, in vitro, mais non sur celle des mycoplasmes souche $T$.; ceci procure donc une méthode biochimique de différenciation des deux plus fréquents mycoplasmes isolés des voies génitales et qui peuvent être assez fréquemment présents dans le même échantillon clinique. L'addition de lincomycine au milieu de culture a facilité et amélioré la détection des mycoplasmes souche $T$. 